\title{
Underwater hearing and communication in the endangered Hawaiian monk seal Neomonachus schauinslandi
}

\author{
Jillian M. Sills ${ }^{1, *}$, Kirby Parnell ${ }^{2,3}$, Brandi Ruscher ${ }^{2}$, Chloe Lew ${ }^{1}$, Traci L. Kendall ${ }^{4}$, \\ Colleen Reichmuth ${ }^{1}$ \\ ${ }^{1}$ Institute of Marine Sciences, Long Marine Laboratory, University of California Santa Cruz, Santa Cruz, CA 95060, USA \\ ${ }^{2}$ Department of Ocean Sciences, University of California Santa Cruz, Santa Cruz, CA 95064, USA \\ ${ }^{3}$ Marine Mammal Research Program, Hawai'i Institute of Marine Biology, University of Hawai'i, Kaneohe, HI 96744, USA \\ ${ }^{4}$ Department of Ecology and Evolutionary Biology, University of California Santa Cruz, Santa Cruz, CA 95064, USA
}

\begin{abstract}
Hawaiian monk seals are among the most endangered marine mammals and the most basal of the phocid seals. The auditory biology of monk seals is compelling from behavioral, evolutionary, and conservation perspectives, but we presently lack substantive bioacoustic information for this species, with no formal descriptions of underwater vocalizations and limited data concerning hearing. These seals have been isolated for more than 10 million yr and have auditory structures differing from those of related species. Additionally, unlike other aquatically mating phocids, monk seals breed asynchronously and are not known to produce social calls in water. To address existing knowledge gaps, we trained a mature male Hawaiian monk seal to perform a psychophysical task while submerged. Detection thresholds were measured for narrowband sounds across the frequency range of hearing. We also conducted a year-round characterization of the seal's spontaneous underwater vocalizations. This individual demonstrated best hearing between 0.2 and $33 \mathrm{kHz}$, with a lower high-frequency roll-off than that of related species. Hearing at all frequencies was less sensitive than in other true seals. Despite the absence of conspecifics, the seal regularly produced 6 different underwater calls with energy below $1 \mathrm{kHz}$. Calling patterns reflected a period of annual reproductive activity lasting about $6 \mathrm{mo}$, coincident with elevated testosterone levels. This study presents the first examination of underwater vocalizations in Hawaiian monk seals, provides insight into the auditory abilities of this species and the evolution of underwater hearing among phocids, and enables improved assessments of noise effects on these vulnerable seals.
\end{abstract}

KEY WORDS: Hawaiian monk seal · Hearing · Audiogram · Communication · Vocal behavior

\section{INTRODUCTION}

The Hawaiian monk seal Neomonachus schauinslandi is an ancient phocid (true seal) of the Monachinae lineage (monk seals, elephant seals, Antarctic seals). These seals are endemic to the main and Northwestern Hawaiian Islands, where they presently face a range of anthropogenic and environ-

\footnotetext{
*Corresponding author: jmsills@ucsc.edu
}

mental disturbances (Carretta et al. 2017). Approximately 1400 individuals remain in the wild population (Carretta et al. 2017), making them one of the most endangered marine mammals. Although Hawaiian monk seals are the focus of significant conservation efforts, little is known about underwater sound production or reception in this species. This knowledge gap limits the ability of conservation

() The authors 2021. Open Access under Creative Commons by Attribution Licence. Use, distribution and reproduction are unrestricted. Authors and original publication must be credited. 
practitioners to monitor monk seals acoustically or to mitigate the potentially negative effects of humangenerated noise in the marine environment.

The reproductive behavior of Hawaiian monk seals may provide some clues into their possible use of underwater sound. Hawaiian monk seals are unique among extant phocids in that they are non-migratory and inhabit a tropical climate with relatively stable environmental conditions and resources. These ecological features enable an atypical breeding strategy in which males compete for access to dispersed estrous females throughout much of the year (Kenyon \& Rice 1959, Atkinson \& Gilmartin 1992, Johanos et al. 1994). Males of other terrestrial- and aquaticbreeding species produce vocalizations associated with reproductive periods, when male-male competition for territories or females is highest (see e.g. Van Opzeeland et al. 2010). Adult males of shore-breeding, strongly sexually dimorphic species - including the monachid northern elephant seals Mirounga angustirostris and southern elephant seals M. leoninaproduce structurally complex airborne vocalizations (Sandegren 1976, Shipley et al. 1986, Sanvito et al. 2007, 2008, Casey et al. 2015) but are not known to produce sounds under water. In contrast, adult males of most aquatically mating species do produce underwater calls during the breeding season (Ketten \& Wartzok 1999, Van Parijs 2003, Southall et al. 2019). As Hawaiian monk seals copulate in water and show slight reverse sexual dimorphism (Kenyon \& Rice 1959, Gilmartin \& Forcada 2009), it is plausible that mature male monk seals of the genera Monachus and Neomonachus also emit underwater sounds during active reproductive periods.

Hawaiian monk seals produce low-frequency vocalizations while on shore, including threats and social sounds as well as mother-pup contact calls (Miller \& Job 1992, Job et al. 1995). There is one anecdotal account in the scientific literature that describes solitary Hawaiian monk seals producing 'foghorn' and 'bark' calls in water (Stirling \& Thomas 2003), but the sounds - opportunistically observed by divers and shared as a personal communication were not recorded, and the sex of the calling individuals was unknown. As the production of underwater calls has not been confirmed for this species (Charrier et al. 2017, Southall et al. 2019), fundamental questions about sound production in Hawaiian monk seals remain unanswered, including those related to the presence or absence of such signals, the typical age and sex of calling individuals, seasonal patterns in sound production, and the types of sounds emitted. Until such data are available, it will not be possi- ble to determine the significance of underwater signaling to reproductive behavior or to use speciestypical vocalizations to enable remote monitoring with passive acoustic methods.

While underwater sound production in Hawaiian monk seals remains largely unstudied, what little is known about hearing ability in this species is perplexing. The majority of auditory data available for seals come from representatives of the Phocinae subfamily (most Northern Hemisphere seals), which have notably similar auditory capabilities (see Reichmuth et al. 2013, Erbe et al. 2016). Phocinae seals have sensitive hearing that spans a broad frequency range in water, extending from below $100 \mathrm{~Hz}$ to above $60 \mathrm{kHz}$. Far less is known about hearing in the Monachinae subfamily of seals. An audiogram exists for a single northern elephant seal (Kastak \& Schusterman 1999): while the reported thresholds are somewhat elevated, the overall hearing profile is generally similar to that of phocinae seals. Some underwater hearing data are also available for one $3 \mathrm{yr}$ old male Hawaiian monk seal (Thomas et al. 1990). However, this audiogram appears anomalous, both with respect to what is known about the wellstudied phocinae seals and about the lesser-studied monachid seals. The reported audiogram suggests that Hawaiian monk seals have a narrow hearing range with a high frequency roll-off around $30 \mathrm{kHz}$ and poor (if any) hearing below $10 \mathrm{kHz}$. This unusual hearing curve would render them unable to detect their own vocalizations in air, as well as most anthropogenic sounds of potential concern.

As monk seals are the earliest diverging lineage within the Monachinae subfamily (Berta \& Churchill 2012), understanding their auditory biology and communication is intriguing from an evolutionary perspective. In particular, what we learn about sound reception abilities in Hawaiian monk seals can provide insight into the evolution of underwater hearing among true seals. Similarities in hearing to phocinae seals would suggest that auditory abilities can be generalized across the phocid lineage (see Southall et al. 2019) and that common adaptations for hearing in water arose more than 20 million yr ago (Berta et al. 2018). While their auditory anatomy differs somewhat from other seals (Repenning \& Ray 1977, Wyss 1988), it remains to be seen whether the hearing abilities of Hawaiian monk seals are unique within their phylogenetic group.

To resolve these discrepancies and address existing data gaps, our aims in the present study were to (1) investigate the underwater auditory abilities of Hawaiian monk seals, (2) determine whether mature 
male seals of this species produce sounds under water, and if so, (3) provide an initial description of their aquatic vocal repertoire. We used behavioral methods with 1 trained Hawaiian monk seal to measure auditory thresholds under quiet conditions in water, which describe absolute (unmasked) sensitivity across the frequency range of hearing. We also obtained year-round, simultaneous acoustic and video recordings for this adult male seal to characterize vocalizations and describe temporal patterns in vocal behavior. To validate these findings, we compared vocal data to those from another captive Hawaiian monk seal and from wild individuals. Improving our understanding of sound reception and sound production in Hawaiian monk seals should inform management of human-generated noise (see Southall et al. 2019) and enable development of passive acoustic monitoring methods, which will strengthen conservation efforts for this vulnerable species.

\section{MATERIALS AND METHODS}

\subsection{Subject}

The primary subject was a male Hawaiian monk seal identified as Kekoa (KE18, NOA0006781), a sexually mature individual who lived in the wild until age 10. After being deemed a threat to the fragile monk seal population due to aggression towards conspecifics, he was removed from the wild by the US National Marine Fisheries Service and brought into human care for participation in long-term cooperative research. For $6 \mathrm{yr}$ prior to the present study, Kekoa was trained using operant conditioning methods and positive reinforcement to participate in husbandry and research tasks at Long Marine Laboratory (University of Santa Cruz). During this time, he was housed without exposure to conspecifics and in facilities approximating the thermal environment of Hawaii.

At the beginning of this study, Kekoa was 15 yr old, weighed approximately $200 \mathrm{~kg}$, and was an apparently healthy individual with no known ear injuries or ototoxic exposures. His interaural distance was $26 \mathrm{~cm}$, measured dorsally as the curvilinear length between meatal openings (linear inter-meatal distance: $21 \mathrm{~cm}$ ). Kekoa typically participated in one audiometric session per day, $5 \mathrm{~d} \mathrm{wk}^{-1}$, and received one-third to one-half of his prescribed daily diet (freshly thawed fish and squid) during this session. His diet was established to maintain optimal health and was not constrained for research purposes. While
Kekoa had no prior history of bioacoustic research, he had been trained to produce one airborne sound on cue in the context of his husbandry training.

Animal research was conducted without harm under authorization from the US National Marine Fisheries Service (permit 19590) in accordance with applicable animal welfare laws in the USA. Oversight of animal care and research activities was provided by the Institutional Animal Care and Use Committee at the University of California Santa Cruz.

\subsection{Underwater hearing}

\subsubsection{Testing environment}

Auditory testing was conducted in a circular, partially in-ground, epoxy-lined concrete pool containing filtered seawater. This $1.8 \mathrm{~m}$ deep, $7.6 \mathrm{~m}$ diameter pool was located adjacent to the seal's living enclosure. Audiometric sessions were controlled remotely from a sound-isolated control room from which a technician could monitor the test pool via underwater cameras.

The pool was made as quiet as possible during audiometric testing; water flow was eliminated, nearby activity was limited, and sessions were only conducted under calm weather conditions. We measured ambient noise daily in these test-ready conditions. A calibrated TC4032 low-noise hydrophone $(0.01-80 \mathrm{kHz}$, $\pm 2.5 \mathrm{~dB}$; Teledyne Reson) with EC6073 input module was used with a self-powered 2270 sound analyzer (sampling rate: $48 \mathrm{kHz}$; Brüel \& Kjær A/S) to measure $1 \mathrm{~min}$, unweighted noise samples for frequencies from $0.04-20 \mathrm{kHz}$. The hydrophone was placed (without the animal present) at the center position of the seal's head during auditory testing. On a subset of days, a battery-powered FR-2 Field Memory Recorder (sampling rate: $192 \mathrm{kHz}$; Fostex Company) was also used with the hydrophone to record ambient noise at frequencies above $24 \mathrm{kHz}$. We calculated percentile statistics of 1/3-octave band levels from $1 \mathrm{~min}$ Leq (equivalent continuous sound pressure level) values. Ambient noise was then described in terms of spectral density levels, which were calculated from the median of $1 / 3$-octave band $50^{\text {th }}$ percentile measurements (L50) over the study period.

\subsubsection{Threshold testing}

We used a behavioral 'go/no-go' signal detection procedure to measure hearing thresholds at 14 fre- 
quencies (Video $\mathrm{S} 1$; for all supplementary video and audio files and Fig. S1 see the Supplement at www. int-res.com/articles/suppl/n044p061_supp/). As Kekoa had no prior experience with auditory testing, he completed extensive training before beginning data collection. After about 7 mo of intermittent training at a variety of frequencies and sound levels, formal testing began in May 2018 and lasted approximately 5 mo.

We conducted daily audiometric sessions to maintain stable performance. At the start of each session, the seal was cued by a trainer to dive to a submerged 'listening station' in the testing enclosure and rest quietly. The water-filled (low impedance) PVC listening station included a chin rest where he could position his head at $1 \mathrm{~m}$ depth, $0.5 \mathrm{~m}$ from the edge of the pool. During each $4 \mathrm{~s}$ trial - which began once Kekoa was settled on the chin rest - he touched the response target to his left when he detected an acoustic signal ('correct detection' on a signal-present trial) and withheld this response when he did not ('correct rejection' on a signal-absent trial). These correct responses were marked with an acoustic buzzer, followed by primary reinforcement (fish) provided by the trainer at the surface. If the subject failed to report a signal detection on a signal-present trial ('miss') or touched the response target on a signal-absent trial ('false alarm'), he was not rewarded but was allowed to proceed to the next trial after a brief surface interval. Signals were included on $50-70 \%$ of trials and presented in a pseudorandom order, with the percentage of signal-present trials manipulated between sessions to maintain a consistent false alarm rate throughout testing. To eliminate the possibility of inadvertent cueing, the trainer received instructions via headphones and was unaware of individual trial conditions.

An adaptive staircase procedure was used to estimate hearing threshold at each frequency (Cornsweet 1962). During a session, signal frequency was held constant while signal amplitude was varied based on subject performance. The first signal-present trial contained an easily detectable signal $\sim 20 \mathrm{~dB}$ above predicted threshold, after which amplitude was decreased by $4 \mathrm{~dB}$ following each correct detection until the first miss. Subsequently, signal amplitude was increased by $4 \mathrm{~dB}$ after each miss and decreased by $2 \mathrm{~dB}$ after each correct detection until 5 hit-to-miss transitions within $6 \mathrm{~dB}$ of one another were obtained. An asymmetrical step-size was used to maintain stimulus control with this relatively naive animal by minimizing errors following misses. The session concluded with several cool-down trials at supra-threshold levels to ensure behavioral control on the task.
Frequencies were tested to completion in random order. For each frequency, sessions were repeated until performance was stable over 3 testing days, with the average level of the hit-to-miss transitions varying by less than $3 \mathrm{~dB}$ and the pooled false alarm rate $^{1}$ between 0 and 0.3 . Threshold was then calculated from signal-present trials using probit analysis (Finney 1971). A psychometric (sigmoid) function was fit to the proportion of correct detections at each signal level, and an inverse prediction was applied to calculate threshold as the sound pressure level (SPL) in $\mathrm{dB}$ re $1 \mu \mathrm{Pa}$ corresponding to the $50 \%$ performance level. Threshold criteria were met when $95 \%$ CIs on the psychometric function were less than $4 \mathrm{~dB}$. The threshold-to-noise offset was calculated as the difference between hearing threshold and ambient noise spectral density level at each test frequency.

\subsubsection{Stimulus generation and calibration}

Auditory thresholds were measured for the monk seal across the frequency range of hearing. Hearing was evaluated in octave steps from $0.1-25.6 \mathrm{kHz}$, a half-octave step to $36.2 \mathrm{kHz}$, and quarter-octave steps to $60.9 \mathrm{kHz}$. Hearing was also measured at $18 \mathrm{kHz}$ to determine whether Kekoa exhibited increased sensitivity in this frequency region, comparable to auditory data reported for the monk seal tested by Thomas et al. (1990). The first frequency tested was re-measured at the end of the study to confirm the absence of a practice effect.

The audiometric signals were narrowband frequency-modulated upsweeps $( \pm 5 \%$ from center frequency) with $500 \mathrm{~ms}$ duration (including $5 \%$ rise and fall times). Signals were generated with the Hearing Test Program (HTP) virtual instrument (Finneran 2003) in LabVIEW software (National Instruments [NI]) and passed through an NI USB-6259 BNC M-series data acquisition module (update rate: $500 \mathrm{kHz}$ ), a 3364 bandpass filter (Krohn-Hite), a PA5 digital attenuator (Tucker-Davis Technologies), and in some cases a P1000 power amplifier (Hafler Professional) prior to reaching the projector. This was either a J-11 speaker (Naval Undersea Warfare Center) for $0.1-3.2$ and $12.8 \mathrm{kHz}$ signals or a 1042 projecting hydrophone (International Transducer Cor-

\footnotetext{
$\overline{1}$ False alarm rate was defined as the proportion of signalabsent trials between the first and fifth hit-to-misstransitions on which the seal incorrectly reported detection of a signal. Responses prior to signal presentation on signalpresent trials were also scored as false alarms
} 
poration) for 6.4 and $18.0-60.9 \mathrm{kHz}$ signals. Both transducers were decoupled from the listening station and suspended into the pool $6 \mathrm{~m}$ behind the subject. The precise configuration depended on frequency and was determined by spatial mapping of the received sound field to confirm acceptable variability $( \pm 3 \mathrm{~dB})$ in received signals within a $14 \times 14 \times$ $14 \mathrm{~cm}$ grid surrounding the listening station.

Signals were also calibrated and inspected daily at the listening station in the absence of the subject. Before every testing session, signals were projected at a range of amplitudes and received with the TC4032 hydrophone. The incoming signals were passed through the same filter, NI hardware, and HTP software used for signal generation. Signals were evaluated in both time and frequency domains and measured in HTP to compare expected with received SPLs.

At the end of the study, measured thresholds and associated ambient noise levels were adjusted based on the frequency-specific sensitivity of the TC4032 hydrophone.

\subsection{Underwater sound production}

\subsubsection{Environment}

The sound production study was conducted in Kekoa's primary living enclosure, a circular, flowthrough seawater pool surrounded by haul-out space. This $2.1 \mathrm{~m}$ deep, $7.6 \mathrm{~m}$ diameter pool was connected to 2 larger pools that housed up to 3 dolphins. A solid gate separated the seal's pool from one enclosure, and a water-filled PVC gate separated the seal's pool from a water-filled channel $(3 \times 1.5 \times 1.5 \mathrm{~m}$ deep) leading to the other enclosure.

Noise in the seal's pool included mechanical sounds, sounds associated with water movement, and sounds emitted by the dolphins in adjacent pools. Median ambient noise spectral density levels were measured with the TC4032 hydrophone and 2270 sound analyzer and calculated as in Section 2.2.1. Noise in the environment generally decreased with increasing frequency from $86 \mathrm{~dB}$ re $(1 \mu \mathrm{Pa})^{2} \mathrm{~Hz}^{-1}$ at $80 \mathrm{~Hz}$ to $67 \mathrm{~dB}$ re $(1 \mu \mathrm{Pa})^{2} \mathrm{~Hz}^{-1}$ at $2 \mathrm{kHz}$.

\subsubsection{Physiological cycles}

This year-long study of sound production began in October 2017, and monk seal Kekoa completed his annual 'catastrophic' molt between 8 February and 13 March. Based on typical annual cycles of wild monk seals (Atkinson \& Gilmartin 1992), this sexually mature seal likely experienced a period of heightened reproductive status lasting several months prior to his molt. To independently evaluate his annual reproductive cycle for comparison with trends in sound production, we measured serum testosterone levels from 6 blood samples obtained during the study period. Bloodwork was conducted at the same analytical lab for all samples (Antech Diagnostics).

\subsubsection{Audio and video recording}

We used a SoundTrap 300 STD acoustic recorder $\left(0.02-60 \mathrm{kHz}_{1} \pm 3 \mathrm{~dB}\right.$; Ocean Instruments) to record Kekoa's spontaneous underwater vocalizations. The recorder was encased in protective, water-filled PVC tubing (with only the hydrophone exposed) and placed within a concrete mount in the water-filled channel adjacent to the seal's primary pool. The hydrophone was at $1.5 \mathrm{~m}$ depth and nearly flush with the circumference of the pool, so that all areas of the pool were within $8 \mathrm{~m}$. The unit was programmed to record for 30 min every hour with a sampling rate of $48 \mathrm{kHz}$.

Simultaneous, time-linked video was obtained via an infrared camera mounted in the seal's enclosure. Data archived by the linked surveillance system later allowed the seal's position during each recorded call to be determined as either 'in water' or 'on deck.'

\subsubsection{Acoustic analyses}

A total of 24 acoustic files were recorded daily and referenced to video data. Of these, we analyzed paired audio-video recordings from the same $2 \mathrm{~d}$ every week for $12 \mathrm{mo}$. Only sounds confirmed by video to be produced in water were considered. Conditioned vocalizations produced by the seal during training sessions, environmental noises, and whistles and clicks produced by dolphins in the adjacent pools were excluded from analysis.

Calls were identified based on visual inspection of spectrograms using Adobe Audition (Adobe), with discrete vocalizations defined as units of sound that could be readily isolated and counted. Sounds produced by the seal were individual calls, or sequences of one or more calls produced in bouts separated by at least $3 \mathrm{~s}$ of silence. Calls considered to be the same vocal type had common perceptual structure, frequency characteristics, and repeatable features that were recognizable and measurable. Upon detection, 
each call was cross-referenced to video data and then logged and scored for subjective quality. Initially, each vocalization was categorized into 1 of 10 call types based on perceptual features. These types were descriptively labeled as 'moan', 'ascending moan', 'descending moan', 'croak', 'groan', 'growl', 'gurgle', 'rumble', 'hum', and 'whoop'. To facilitate review and categorization of call types, we used representative sound files and spectrographic exemplars to train 3 observers who examined the entire data set.

To formally describe the perceptual call types in the seal's repertoire, we conducted spectrographic analysis with a subsample of 20 representative calls of each type. These were high-quality calls with signal-to-noise ratios (SNR) greater than $15 \mathrm{~dB}$. Seventeen spectral and temporal features were measured from each call using Raven Pro 1.5 (Cornell Lab of Ornithology). These features (see descriptions and abbreviations in Table 2) included total duration, $90 \%$ duration, center frequency, inter-quartile range bandwidth (and $1^{\text {st }}$ and $3^{\text {rd }}$ quartile frequencies), $90 \%$ bandwidth (and upper and lower frequency bounds), peak frequency, $3 \mathrm{~dB}$ bandwidth (and upper and lower frequency bounds), $10 \mathrm{~dB}$ bandwidth (and upper and lower frequency bounds), and aggregate entropy. Total call duration was determined by manual selection from the waveform, while frequency parameters were measured from the spectrum over the $90 \%$ duration of the call 2 . In addition to spectral and temporal parameters, call amplitude was measured in $\mathrm{dB}$ rms over the $90 \%$ duration of each call; received SPL (at the position of the hydrophone) was measured in Raven Pro 1.5 and referenced to a calibration tone recorded on the SoundTrap 300 STD with a 42AA pistonphone (GRAS Sound and Vibration).

In addition to parameters measured for all calls, further parameters were measured for a subset of call types. Descriptive features observed from the spectrogram or spectrum of each call were noted, including the presence or absence of harmonics and the number of harmonics contained in the call. For calls containing harmonics (ascending moan, moan, groan), we measured fundamental frequency. For whoops, the inter-unit interval, number of units per bout, and number of units per second were meas-

\footnotetext{
ㄴving the $90 \%$ duration enabled consistent (automated) measurement rather than subjective measurement of call duration. For whoops, $90 \%$ duration sometimes fell below the minimum window dictated by the sampling rate $(0.0853 \mathrm{~s})$. In these cases, the minimum window allowed by the sampling rate was used for analysis; this was always within $0.03 \mathrm{~s}$ of the $90 \%$ duration
}

ured. For rumbles - the only call with discrete pulses - pulse duration, inter-pulse interval, number of pulses, and pulse rate were evaluated; these temporal features were measured using Avisoft SAS Lab Pro v.5.2.12 (Avisoft Bioacoustics).

To validate our initial perceptual categorization of call types, a preliminary cross-validated discriminant function analysis (DFA) using the leave-one-out method was conducted based on the 17 spectral and temporal variables measured. Eight of 10 initial call types were considered; descending moans and hums were excluded from the cross-validated DFA due to low encounter rates $(<15$ total calls) or poor SNRs $(<15 \mathrm{~dB})$ that prevented spectrographic analysis. The cross-validated DFA provided a matrix of percent correct classification scores, which indicated how well call variables separated into the pre-assigned call types. When this analysis was complete, we noted whether any 2 call types were consistently confused (misclassification rates $>30 \%$ ). When this occurred, the confounding call types were collapsed into a single category. With a collapsed repertoire of 6 call types, a DFA (no cross-validation) was conducted to plot the call types in acoustic space, with pre-assigned subjective call types as group identifiers and acoustic measurements as discriminant variables. A cross-validated DFA was then computed for those 6 call types. To assess significant differences between the linear discriminants LD1 and LD2, we used a 1-way ANOVA (not assuming equal variances). The 'mass' and 'seewave' packages in RStudio v.1.2.1335 and R v.3.6.1 (R Core Team 2019) were used for this DFA analysis and to create spectrogram figures, respectively.

Manual call counts from the biweekly analysis were used to support characterization of temporal patterns in sound production. For diurnal analysis, call production was summarized for each month as the mean number of calls per 30 min file for each hourly interval. To describe annual patterns in vocal behavior, mean call production (calls per 30 min file) was summarized for each month, both by total number of calls and by call type. Seasonal patterns in calling were further referenced to the seal's physiological cycles as tracked by serum testosterone levels and molting period.

\subsubsection{Validation of vocal repertoire with second adult male}

To validate the 6 call types produced by Kekoa, supplemental recordings of another adult 
male Hawaiian monk seal, identified as Ho'ailona (KP2, NOA0006753), were obtained at the Waikiki Aquarium in Honolulu, Hawai'i. While this individual was born in the wild, he was primarily raised in captive care. From 2011 through 2018, Ho'ailona lived in an enclosure adjacent to an adult male Hawaiian monk seal. During the recording period, he was $11 \mathrm{yr}$ old and housed without exposure to conspecifics in a $6.1 \mathrm{~m}$ wide, $27 \mathrm{~m}$ long, $3.7 \mathrm{~m}$ deep pool.

Recordings were obtained intermittently between April and September 2019 in the period leading up to Ho'ailona's annual molt, using similar methods to those described in Section 2.3.3. The SoundTrap 300 STD was placed in Ho'ailona's living enclosure behind an acoustically transparent gate that prevented his access. Background noise was measured with the SoundTrap 300 STD and spectral density levels were calculated using similar methods to those described in Section 2.2.1. Noise levels decreased from $90 \mathrm{~dB}$ re $(1 \mu \mathrm{Pa})^{2} \mathrm{~Hz}^{-1}$ at $80 \mathrm{~Hz}$ to $42 \mathrm{~dB}$ re $(1 \mu \mathrm{Pa})^{2} \mathrm{~Hz}^{-1}$ at $2 \mathrm{kHz}$.

Recorded files were manually screened for the presence of vocal activity. Calls were identified and classified by experienced observers based on visual inspection of spectrograms using Adobe Audition. No further spectrographic analyses were conducted. Calls were not referenced to video, as the monk seal was acoustically isolated from other species in the facility and it was aurally evident whether the sounds were produced under water or in air.

\subsubsection{Validation of vocal repertoire with unpublished observational data}

To validate our observations of sound production in captive seals, we surveyed global video sharing databases for recordings containing the underwater vocalizations of wild monk seals. Source data included documentary footage owned by private companies and videos in the public domain (e.g. youtube.com, Instagram. com). When possible, we determined the age class and sex of calling seals and qualitatively compared their vocalizations to the 6 call types produced by Kekoa.

\section{RESULTS}

\subsection{Sound reception}

Underwater hearing thresholds measured in quiet conditions are provided in Table 1 for Hawaiian monk seal Kekoa, along with corresponding 95\% CIs, false alarm rates, ambient noise levels, and threshold-to-noise offsets at each frequency. The audiogram is provided in Fig. 1 with the associated environmental noise floor, representative auditory data for northern and southern seals, and the estimated group audiogram for Phocid Carnivores in Water (Finneran 2016, National Marine Fisheries Service 2018, Southall et al. 2019). The psychometric functions associated with these hearing thresholds are provided in Fig. S1.

This monk seal's underwater hearing profile was broad and flat between 0.8 and $25.6 \mathrm{kHz}$, aside from an upward notch around $6.4 \mathrm{kHz}$. Peak sensitivity of $73 \mathrm{~dB}$ re $1 \mu \mathrm{Pa}$ was measured at $1.6 \mathrm{kHz}$, and the $20 \mathrm{~dB}$ range of most sensitive hearing (frequency band of thresholds within $20 \mathrm{~dB}$ of peak sensitivity, as in Reichmuth et al. 2013) fell between approximately 0.2 and $33 \mathrm{kHz}$. Sensitivity decreased above

Table 1. Underwater hearing thresholds obtained for 1 Hawaiian monk seal using behavioral methods. The $50 \%$ detection thresholds are shown for each of 14 frequencies; psychometric functions associated with these hearing thresholds are provided in Fig. S1. Also provided for each test frequency are $95 \%$ CIs, false alarm (FA) rates (pooled across the 3 final sessions at each frequency, $\mathrm{n}=18-52$ signal-absent trials between the first and fifth hit-to-miss transitions), and ambient noise levels during testing. Noise levels are shown in units of power spectral density, calculated from the median of unweighted, $1 / 3$-octave band $50^{\text {th }}$ percentile measurements (L50) surrounding each test frequency. Finally, threshold-to-noise offsets are given as the difference between measured threshold and ambient noise power spectral density level at each frequency

\begin{tabular}{|lccccc|}
\hline $\begin{array}{l}\text { Frequency } \\
(\mathrm{kHz})\end{array}$ & $\begin{array}{c}\text { Threshold } \\
(\mathrm{dB} \text { re } \\
1 \mu \mathrm{Pa})\end{array}$ & $\begin{array}{c}95 \% \mathrm{CI} \\
(\mathrm{dB} \text { re } \\
1 \mu \mathrm{Pa})\end{array}$ & $\begin{array}{c}\text { FA } \\
\text { rate }\end{array}$ & $\begin{array}{c}\text { Ambient noise } \\
\text { power spectral } \\
\text { density }(\mathrm{dB} \text { re } \\
\left.[1 \mu \mathrm{PPa}]^{2} \mathrm{~Hz}^{-1}\right)\end{array}$ & $\begin{array}{c}\text { Threshold- } \\
\text { to-noise } \\
\text { offset }(\mathrm{dB})\end{array}$ \\
\hline 0.1 & 106 & $104-107$ & 0.15 & 73 & 32 \\
0.2 & 95 & $93-95$ & 0.13 & 68 & 27 \\
0.4 & 89 & $87-90$ & 0.19 & 59 & 30 \\
0.8 & 74 & $73-75$ & 0.22 & 53 & 21 \\
1.6 & 73 & $73-74$ & 0.17 & 43 & 30 \\
3.2 & 76 & $75-77$ & 0.21 & 36 & 40 \\
6.4 & 83 & $81-84$ & 0.03 & 31 & 52 \\
12.8 & 79 & $77-80$ & 0.20 & 31 & 39 \\
18.0 & 73 & $72-74$ & 0.20 & 35 & 76 \\
25.6 & 78 & $77-79$ & 0.15 & 25 & 101 \\
36.2 & 99 & $98-100$ & 0.22 & 23 & 114 \\
43.1 & 124 & $124-125$ & 0.19 & 23 & 23 \\
51.2 & 130 & $129-131$ & 0.05 & 23 & \\
60.9 & 137 & $135-138$ & 0.18 & 23 & \\
\hline
\end{tabular}




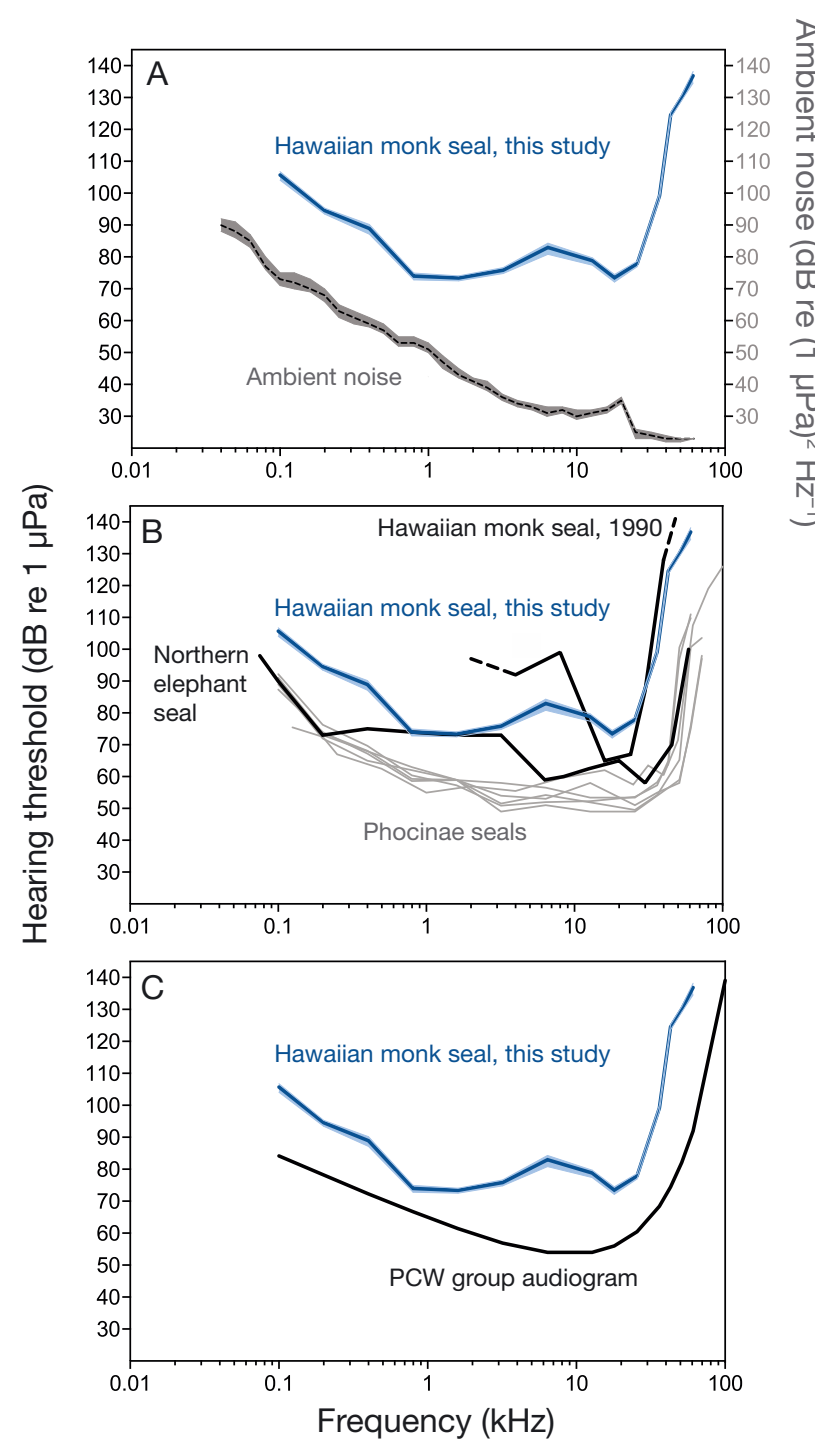

and below this range, rolling off more steeply at high frequencies; above $33 \mathrm{kHz}$, thresholds increased by approximately $35 \mathrm{~dB}$ within a half octave. The reported audiogram is narrower and shallower than those of other seals - and is fully circumscribed by the Phocid Carnivores in Water group audiogramalthough it most closely resembles that of the northern elephant seal (Kastak \& Schusterman 1999).

Mean false alarm rate for the monk seal during audiometric testing was 0.16 (range: 0.03-0.22). Threshold-to-noise offsets in the testing enclosure ranged from 21-114 dB.

\subsection{Sound production}

Hawaiian monk seal Kekoa produced lowfrequency sounds both above and below the water's
Fig. 1. Underwater audiogram for Hawaiian monk seal Kekoa, obtained using behavioral methods. Corresponding hearing data are provided in Table 1, and psychometric functions are plotted in Fig. S1. The $95 \%$ CIs are depicted as shading surrounding the audiogram (solid line), which is plotted in all 3 panels. (A) Ambient noise in the testing environment is plotted with the audiogram in units of power spectral density, corresponding to the right-hand $y$-axis. This noise profile was calculated from the median of unweighted $1 / 3$-octave band $50^{\text {th }}$ percentile levels (L50, dashed line) measured throughout testing; variability in ambient noise is represented by the shaded region above (L10) and below (L90). (B) For comparison, Kekoa's hearing curve is plotted alongside behavioral audiograms for other true seals. The available hearing data for the Monachinae subfamily includes audiograms for the northern elephant seal (n $=1$; Kastak \& Schusterman 1999) and the Hawaiian monk seal ( $\mathrm{n}=1$; Thomas et al. 1990); note that dashes at the edges of the Thomas et al. (1990) audiogram depict preliminary data. Representative audiograms are provided for seals in the Phocinae subfamily as thin lines for bearded ( $n=2$; Sills et al. 2020), ringed $(\mathrm{n}=1$; Sills et al. 2015), spotted $(\mathrm{n}=2$; Sills et al. 2014), and harbor seals ( $\mathrm{n}=2$; Kastelein et al. 2009). (C) For reference, Kekoa's audiogram is shown with the recently updated Phocid Carnivores in Water (PCW) group audiogram proposed by Finneran (2016), National Marine Fisheries Service (2018), and Southall et al. (2019)

surface throughout much of the year. Numerous airborne calls were present in the underwater recordings, which were transmitted to the hydrophone through the air-water interface or conducted into the water through the rigid wooden decks and concrete structure of the pool. We noted and descriptively classified these calls but did not analyze them further ${ }^{3}$.

\footnotetext{
$\overline{3}$ Kekoa produced aerial vocalizations frequently, during every month of the study period. Each of the primary sound types produced in water were also produced by this monk seal while resting on land. One vocalization emitted almost exclusively in air was a pulsed humming sound produced in bouts that typically lasted between 5 and $30 \mathrm{~s}$. During emission of this sound, the seal's throat area visibly pulsated with each hum and no exhalation was observed. This nearly continuous, low-frequency, low-amplitude vocalization was similar to the 'huh-huhs' produced by wild female monk seals while nursing their pups on shore or prior to giving birth (Miller \& Job 1992)
} 
Only underwater vocalizations were used to characterize vocal repertoire and describe temporal patterns in vocal behavior, as reported below.

\subsubsection{Underwater vocal repertoire}

In the initial cross-validated DFA based on 8 presumptive vocal types, 2 perceptual categories (ascending moan, gurgle) had misclassification rates greater than $30 \%$. Half of the ascending moans were classified as moans, while $35 \%$ of gurgles were classified as growls. Therefore, ascending moans and moans were re-classified as moans, and gurgles and growls were re-classified as growls for the subsequent DFA using only 6 vocal types.

The DFA (no cross-validation) extracted 5 functions based on these 6 primary call types, with the first (LD1) and second (LD2) accounting for 60 and $24 \%$ of total variance, respectively (Fig. 2). LD1 was most strongly correlated with aggregate entropy (AE), whereas LD2 was most strongly correlated with duration (DUR). This DFA also revealed significant differences among vocal types (LD1: $F_{5,60}=143$, $\mathrm{p}<0.001 ;$ LD2: $\left.F_{5,63}=42, \mathrm{p}<0.001\right)$.

The cross-validated DFA correctly classified an average of $65 \%$ of vocalizations as their subjective call type. Five of 6 call types were robustly separated in acoustic space and reliably classified by the crossvalidated DFA, as compared to prior (chance) proba- bility of the final call groupings (Fig. 2). Correct classification rates were high for moans (92\% correct classification, chance level $26 \%, \mathrm{n}=40$ calls), growls (80\% correct classification, chance level $26 \%, n=40$ calls), rumbles (65\% correct classification, chance level $13 \%, \mathrm{n}=20$ calls), whoops (60\% correct classification, chance level $13 \%, \mathrm{n}=20$ calls), and croaks (60\% correct classification, chance level $13 \%, n=20$ calls). Croaks and whoops were sometimes confused with one another, with $25 \%$ of croaks misidentified as whoops and $20 \%$ of whoops misidentified as croaks. Groans had the lowest correct classification rate $(35 \%$ correct classification, chance level 13\%, $\mathrm{n}=20$ calls), with $45 \%$ of groans classified as moans by the cross-validated DFA. All vocalizations were correctly classified at rates higher than predicted by chance. Therefore, this monk seal had a vocal repertoire of at least 6 call types with perceptually recognizable acoustic features, as described individually below and in Table 2, Fig. 3, and Audio S1. Calls were often produced in series (Fig. 3, lower panel), with $90 \%$ (3462 of 3858) of underwater vocalizations produced in bouts of 2 or more discrete or contiguous calls.

Croaks were brief (DUR: $0.28 \pm 0.06 \mathrm{~s}$ ), lowfrequency, guttural calls. They were relatively broadband (90\% bandwidth [BDW90]: $271 \pm 115 \mathrm{~Hz}$ ) with no harmonics, and structurally similar to growls but of much shorter duration. Croaks were always discrete and occurred both as isolated signals and

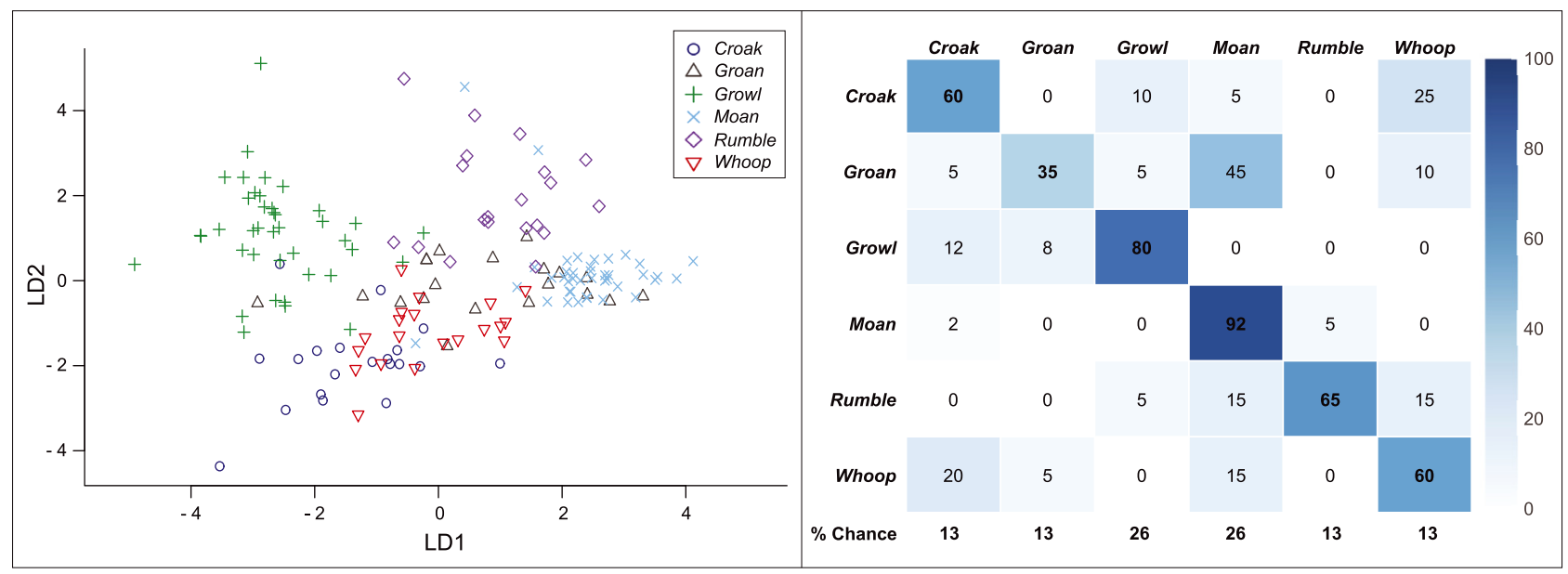

Fig. 2. Discriminant function analysis (DFA) scatterplot (left) and cross-validated DFA matrix (right) for the 6 discrete call types produced under water by Hawaiian monk seal Kekoa ( $\mathrm{n}=40$ for moan and growl; $\mathrm{n}=20$ for croak, groan, rumble, and whoop). Seventeen acoustic parameters were included in the DFA (see Table 2); LD1 explained $60 \%$ of the total variance and correlated most strongly with aggregate entropy while LD2 explained $24 \%$ of the total variance and correlated most strongly with call duration. The cross-validated DFA classification matrix (right) shows the percent of correctly classified calls by type. Darker colors indicate higher classification rates. All call types were correctly classified by the cross-validated DFA at a rate higher than would be expected by chance (shown below the matrix) 


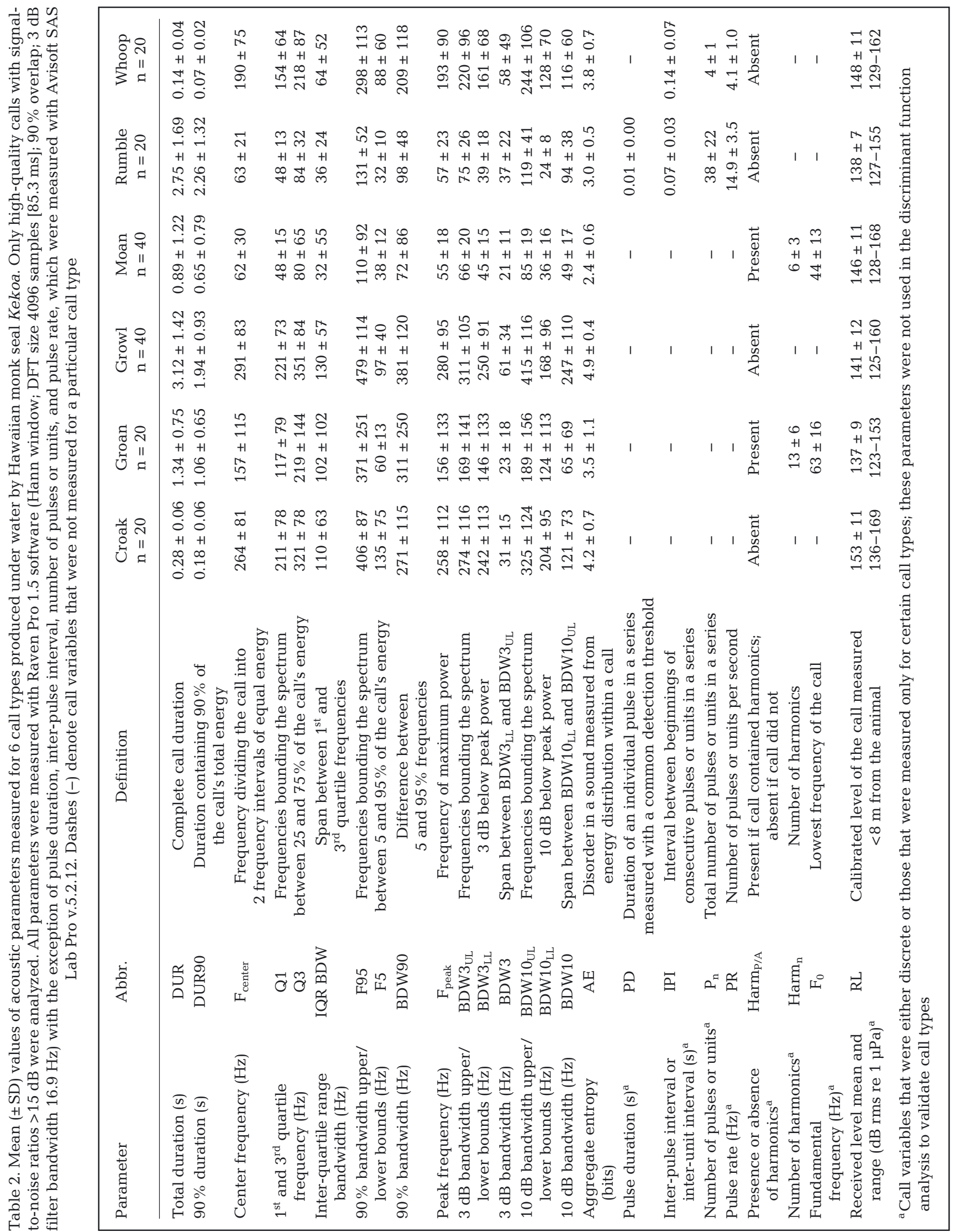



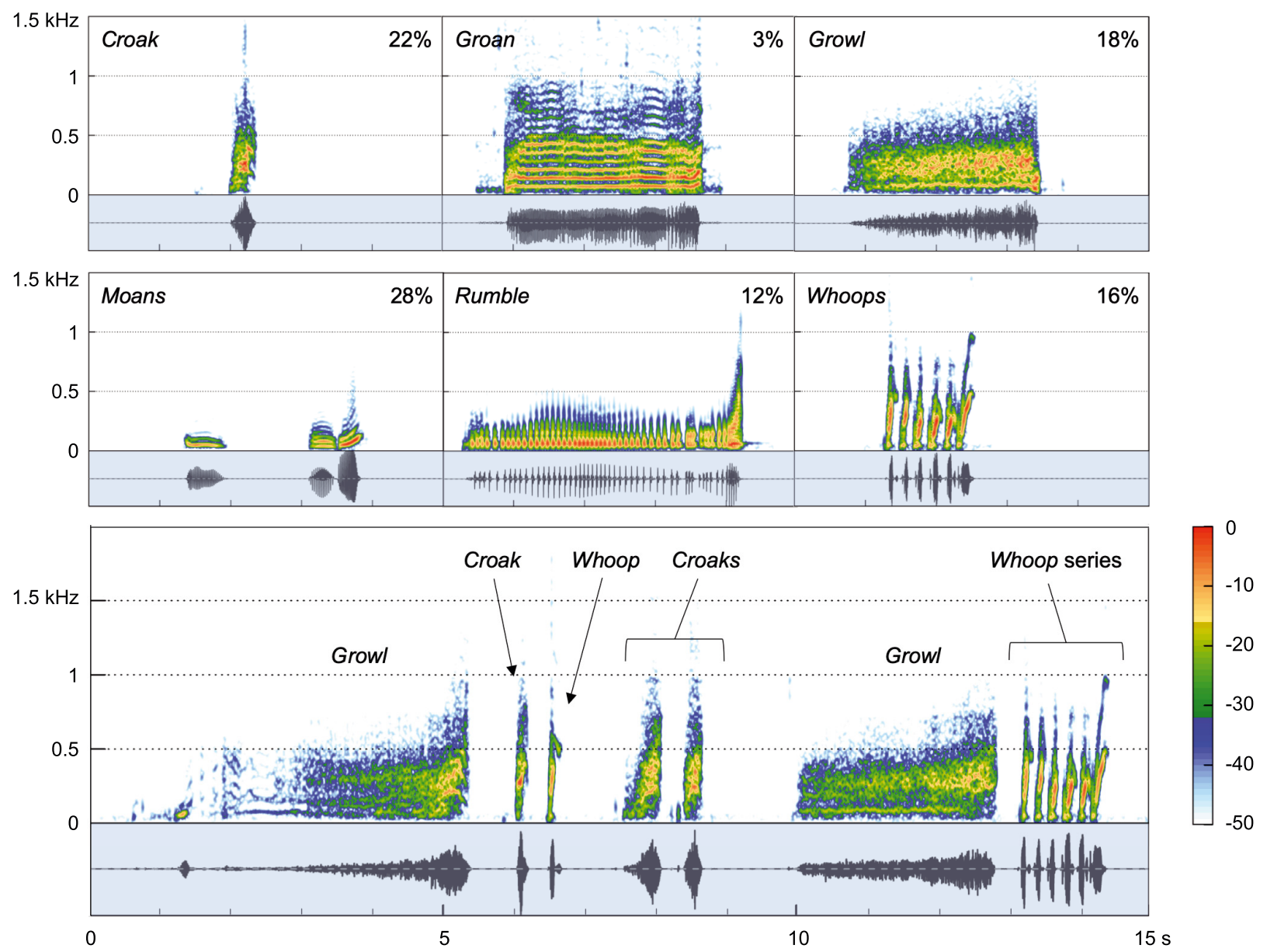

Fig. 3. Spectrograms for the 6 discrete call types produced under water by Hawaiian monk seal Kekoa (upper panels); also shown is a representative vocal bout for this individual (bottom panel). Corresponding waveforms - in the shaded regions below the spectrograms - represent the relative amplitude of each vocalization. The spectrogram amplitude scalebar applies to all spectrograms. The percentage of total vocalizations for each call type produced in a 1 yr period ( $\mathrm{n}=3858 \mathrm{calls})$ is shown in the upper right corner of each panel. Note that in the 'moans' panel, an ascending moan is shown following the second moan. Spectrogram settings: Hann window, window length 4096 points, $90 \%$ overlap, $3 \mathrm{~dB}$ filter bandwidth $16.9 \mathrm{~Hz}$

within vocal bouts. They were perceptually similar to whoops but with a higher peak frequency $\left(\mathrm{F}_{\text {peak }}: 258\right.$ $\pm 112 \mathrm{~Hz})$, slightly longer duration, and greater AE. The mean received level for croaks $(<8 \mathrm{~m}$ distance) was $153 \mathrm{~dB}$ re $1 \mu \mathrm{Pa}$ (range: $136-169 \mathrm{~dB}$ re $1 \mu \mathrm{Pa}$ ).

Groans were relatively long (DUR: $1.34 \pm 0.75 \mathrm{~s}$ ), low-frequency vocalizations that sounded similar to a foghorn or a bellow. Groans were structurally similar to moans and ascending moans but reached higher frequencies (F95: $371 \pm 251 \mathrm{~Hz})$, had a greater fundamental frequency $\left(\mathrm{F}_{0}: 63 \pm 16 \mathrm{~Hz}\right)$, contained more harmonics $\left(\operatorname{Harm}_{\mathrm{n}}\right.$ : $13 \pm 6$, range: 3-22), and were somewhat noisier (AE: $3.5 \pm 1.1$ bits). Groans were always discrete and occurred as isolated signals and within vocal bouts. We note that the groan vocalization Kekoa produced spontaneously in water was qualitatively similar to the conditioned vocalization he produced in air in response to a trainer's prompt. The mean received level for groans ( $<8 \mathrm{~m}$ distance) was $137 \mathrm{~dB}$ re $1 \mu \mathrm{Pa}$ (range: $123-153 \mathrm{~dB}$ re $1 \mu \mathrm{Pa}$ ).

Growls were longer in duration (DUR: $3.12 \pm 1.42 \mathrm{~s}$ ) than croaks, but were similarly low-frequency, harsh, broadband signals (BDW90: $381 \pm 120 \mathrm{~Hz}$ ). Growls and croaks had the highest $\mathrm{AE}$ of the 6 call types $(4.9 \pm 0.4$ and $4.2 \pm 0.7$ bits, respectively). Growls lacked harmonics and were sometimes preceded by and connected to ascending moans. They tended to increase in amplitude and frequency over the duration of the call. The mean received level for growls (<8 m distance) was $141 \mathrm{~dB}$ re $1 \mu \mathrm{Pa}$ (range: 125$160 \mathrm{~dB}$ re $1 \mu \mathrm{Pa}$ ).

Moans were brief (DUR: $0.89 \pm 1.22 \mathrm{~s}$ ), low-frequency ( $\mathrm{F}_{\text {peak }}: 55 \pm 18 \mathrm{~Hz}$ ), relatively tonal calls with a lower fundamental frequency $\left(\mathrm{F}_{0}: 44 \pm 13 \mathrm{~Hz}\right)$ and 
fewer harmonics than groans $\left(\operatorname{Harm}_{\mathrm{n}}\right.$ : $6 \pm 3$, range: 2-15). Moans had the lowest AE ( $2.4 \pm 0.6$ bits) of the 6 vocal types. The moan, which was relatively flat in frequency profile, had 2 variations: ascending and descending. Ascending moans had a minor frequency upsweep. They often followed moans and preceded growls. The descending moan was a rare variation of the moan that resembled a slight downsweep. The mean received level for moans ( $<8 \mathrm{~m}$ distance) was $146 \mathrm{~dB}$ re $1 \mu \mathrm{Pa}$ (range: $128-168 \mathrm{~dB}$ re $1 \mu \mathrm{Pa}$ ).

Rumbles were pulsed (pulse rate, PR: $14.9 \pm 3.5 \mathrm{~Hz} ; \mathrm{P}_{\mathrm{n}}$ : $38 \pm 22$ ), low-frequency ( $\mathrm{F}_{\text {peak }}: 57 \pm 23 \mathrm{~Hz}$ ), relatively long-duration calls (DUR: $2.75 \pm 1.69 \mathrm{~s}$ ). Occasionally, rumbles occurred as isolated signals, but were typically associated with moans and were often followed by and connected to ascending moans. The mean received level for rumbles ( $<8 \mathrm{~m}$ distance) was $138 \mathrm{~dB}$ re $1 \mu \mathrm{Pa}$ (range: $127-155 \mathrm{~dB}$ re $1 \mu \mathrm{Pa}$ ).

Whoops were brief calls (DUR: $0.14 \pm 0.04 \mathrm{~s}$ ) that occurred as an individual element or in a series of 2-6 repeating elements with a regular inter-unit interval (IPI: $0.14 \pm 0.07 \mathrm{~s}$ ). We counted individual or multiple whoops as a single call when the interval between successive whoops was less than $0.5 \mathrm{~s}$. Whoops were perceptually similar to croaks but had lower $\mathrm{AE}(3.8 \pm 0.7 \mathrm{bits})$, a steeper frequency upsweep, and a lower peak frequency $\left(\mathrm{F}_{\text {peak }}: 193 \mathrm{~Hz}\right.$ \pm 90 ). Within a bout of whoops, the peak frequency for individual whoops varied. The mean received level for whoops ( $<8 \mathrm{~m}$ distance) was $148 \mathrm{~dB}$ re $1 \mu \mathrm{Pa}$ (range: $129-162 \mathrm{~dB}$ re $1 \mu \mathrm{Pa}$ ).

\subsubsection{Temporal patterns in vocal behavior}

We screened $1152 \mathrm{~h}$ of acoustic data and found 3858 vocalizations produced in water. The maximum calling rate observed was 92 calls per 30 min file. Calls were detected during the day and night, although vocal behavior was generally highest near dawn. Additional details describing diurnal patterns are provided in Parnell (2018). There was a strong seasonal pattern in calling (Fig. 4). Call production was highest between August and January and peaked in December, during the suspected breeding season. The number of vocalizations produced decreased markedly by February and remained low until July, during and following the annual molt. This pattern was evident for all vocal types, with none of the 6 call types emitted only during the suspected breeding season. Kekoa's blood testosterone values tracked call production (Fig. 4). Testosterone was highest in September and December 2017 (201 and $304 \mathrm{ng} \mathrm{dl}^{-1}$, respectively), decreased drastically in February, April, and May $\left(53,<20,41 \mathrm{ng} \mathrm{dl}^{-1}\right)$, and began to increase again the following September (83 $\mathrm{ng} \mathrm{dl}^{-1}$ ).

\subsubsection{Validation of vocal repertoire with second adult male}

We screened $567 \mathrm{~h}$ of acoustic data for monk seal Ho'ailona at Waikiki Aquarium and identified 1211 calls. We found that Ho'ailona produced all 6 of the call types emitted by Kekoa (see Audio S2), as well as 1 additional sound. The 'snort' was of short duration $(<0.5 \mathrm{~s})$, faint, and structurally similar to whoops, but aurally seemed to be accompanied by a greater release of air. Growls were the most common calls detected $(30 \%)$, followed by croaks $(29 \%)$, whoops $(7 \%)$, rumbles $(5 \%)$, groans $(5 \%)$, and moans $(4 \%)$. Snorts comprised $20 \%$ of emitted sounds. Calls emitted by Ho'ailona were in the same frequency range as Kekoa's vocalizations, with similar structural char- 
acteristics including energy distribution, spectral shape, and duration. However, Ho'ailona's calls were produced fairly continuously within bouts, whereas Kekoa's vocalizations were typically more discrete signals within bouts.

\subsubsection{Validation of vocal repertoire} with unpublished observational data

Our search for video footage generated many observations of monk seals in exploratory and social contexts but relatively few video recordings containing seal vocalizations. Evidence of Hawaiian monk seal underwater vocal behavior was found in documentary archival footage and public videos from recreational divers and snorkelers. In all cases, such videos featured larger seals and — when sex could be determined - at least one male individual. Video S2 provides several examples of free-ranging monk seals; the vocalizations audible in these recordings correspond to the croak, growl, and whoop call types described for Kekoa.

\section{DISCUSSION}

\subsection{Underwater sound reception}

Underwater auditory thresholds obtained for 1 Hawaiian monk seal show reduced sensitivity across the frequency range of hearing relative to related species. In terms of peak sensitivity, this monk seal also exhibited elevated thresholds compared to the one Hawaiian monk seal tested previously (Thomas et al. 1990). Overall, the audiogram obtained in this study does not correspond well with published data for this species or with audiograms for other phocid seals tested to date.

Relatively high threshold-to-noise offsets indicate that background noise did not influence threshold measurement, and thus cannot explain the elevated thresholds measured for this seal. In general, threshold-to-noise offsets should be compared to speciesspecific critical ratios at each frequency to determine whether auditory thresholds were constrained by environmental noise. Critical ratios are not yet available for Hawaiian monk seals. However, based on data for the monachid northern elephant seal and related species (see Erbe et al. 2016 for review), the offsets determined here generously exceed predicted critical ratios at every frequency. Similarly, false alarm rates observed throughout testing indi- cate that this seal's response bias was not so conservative as to impede measurement of absolute auditory thresholds.

Despite generally high measured thresholds ( $\geq 73 \mathrm{~dB}$ re $1 \mu \mathrm{Pa}$ ), results demonstrated that Hawaiian monk seals hear better at low frequencies than was previously believed. While prior data suggested insensitivity to sounds below $10 \mathrm{kHz}$, the present study shows that this species can detect lowfrequency sounds extending to at least $100 \mathrm{~Hz}$. Given their vocal repertoire both on shore and in water, this finding makes sense. This result also emphasizes that the impacts of low-frequency anthropogenic noise sources cannot be discounted for this species, as has been previously suggested (e.g. Advanced Research Projects Agency \& National Oceanic and Atmospheric Administration 1995).

Notably, despite considerable differences in reported thresholds, there was agreement on the high frequency roll-off between this study and the underwater audiogram reported for another individual (Thomas et al. 1990). This close correspondence confirms that Hawaiian monk seals have a lower limit of high-frequency hearing than the other 6 seal species for which similar data are available (out of 18 extant phocid species). High-frequency sensitivity declines sharply about 1/2-octave lower in these monachid seals. While this difference is not necessarily significant from an ecological standpoint, it does confirm that this basal species does not show the derived trait of extreme high-frequency hearing that has been demonstrated in the Phocinae subfamily of seals and the monachid northern elephant seal. Therefore, it is apparent that an expanded frequency range of underwater hearing evolved at some point after monk seals diverged from the rest of the phocid lineage. While the monk seal audiogram is most similar to that of the northern elephant seal - which could suggest common auditory traits in the Monachinae relative to the Phocinae subfamily - more auditory data for monachid species are needed to resolve patterns of hearing within the phocid lineage of seals.

From an applied perspective, this audiogram can be considered with respect to recent regulatory guidance for marine mammals (Finneran 2016, National Marine Fisheries Service 2018, Southall et al. 2019). Specifically, the Phocid Carnivores in Water species grouping fully captures the hearing ability of Hawaiian monk seals, although it is likely somewhat conservative in terms of managing noise effects. While Hawaiian monk seals apparently have better lowfrequency hearing - and are therefore more vulnerable to the effects of anthropogenic noise in the 
environment - than was previously believed, their auditory thresholds are elevated across the full range of hearing relative to the Phocid Carnivores in Water group audiogram.

\subsection{Underwater sound production}

Our results indicate that male Hawaiian monk seals produce underwater vocalizations and possess a vocal repertoire of at least 6 call types. The descriptions of underwater sound production presented herein are the first available for the species, confirming sparse anecdotal observations suggesting a role for acoustic signaling in monk seal underwater social communication (Stirling \& Thomas 2003).

The underwater vocal repertoire of male monk seal Kekoa included croaks, groans, growls, moans, rumbles, and whoops, with ascending and descending moans and hums as potential additional call types. All sounds were uniformly low in frequency content, with most spectral energy below $1 \mathrm{kHz}$ and peak frequencies less than $300 \mathrm{~Hz}$. Supplementary data collected with another captive male monk seal, Ho'ailona, confirmed the production of these same 6 vocal types and one additional sound, the snort. Underwater vocalizations present in opportunistic recordings of wild monk seals (see Video S2) provide further support for these findings. The spectral features of the 6 primary vocalizations described in this study - which overlap with the frequency region of best hearing for the same individual - suggest that Hawaiian monk seals rely on low-frequency signals to communicate under water.

Interestingly, 3 of Kekoa's underwater vocalizations closely resembled airborne vocalizations reported for wild Hawaiian monk seals during the reproductive season. The whoop, croak, and growl call types produced by Kekoa in water align with the 'bubble', 'guttural expiration', and 'roar' vocalizations produced by monk seals on shore (Miller \& Job 1992). Additionally, the qualitative description of 'rolling bellows' emitted by adult male monk seals attending females on beaches (Kenyon \& Rice 1959, Johnson \& Johnson 1984) seems comparable to Kekoa's underwater groan. These calls had similar frequency and duration characteristics whether recorded above or below the water's surface, suggesting that at least some call types can be produced amphibiously.

Despite asynchronous breeding and molting behavior, Hawaiian monk seals apparently exhibit some degree of seasonality in underwater calling. Kekoa's highest vocalization rates were observed in the 6 mo prior to his annual catastrophic molt, with a sharp decline afterwards followed by minimal vocal activity in subsequent months. With few exceptions, other aquatically mating male seals from both the Monachinae (e.g. Thomas \& DeMaster 1982, Green \& Burton 1988, Riedman 1990, Rogers et al. 1996, Van Opzeeland et al. 2010) and Phocinae lineages (e.g. Stirling 1973, Calvert \& Stirling 1985, Van Parijs et al. 1999, 2001, Reichmuth \& Schusterman 2009) also call under water primarily during their respective breeding seasons. However, the extended interval of increased calling behavior we observed for this monk seal is remarkable and appears to exceed that reported for both temperate and polar seals, with the possible exception of the Weddell seal (Van Opzeeland et al. 2010).

The observed correlation between Kekoa's underwater calling rates and serum testosterone levels, even in the absence of conspecifics, indicates that vocal behavior is linked to reproductive activity in Hawaiian monk seals. Kekoa's blood testosterone values were on average 5 fold higher in the months leading up to the annual molt than during and following the molting period. This pattern is generally consistent with hormonal profiles obtained from 4 captive monk seals, whose testosterone levels peaked 6 mo prior to the annual molt and were lowest in the months following molt (Atkinson \& Gilmartin 1992). As circulating testosterone values increase during the breeding season for most mammals (Lincoln \& Short 1980), heightened vocal behavior and testosterone levels within the 6 mo prior to Kekoa's molt both suggest a prolonged breeding season extending from at least August through January for this individual.

At a population level, the Hawaiian monk seal breeding season extends over at least a 9 mo interval (Miller \& Job 1992), with whelping occurring throughout much of the year and peaking in spring and summer (Johnson \& Johnson 1984, Johanos et al. 1994). The tropical, aseasonal climate of the Hawaiian archipelago allows female seals to give birth throughout the year, unlike temperate and polar phocids who are constrained by strong seasonal shifts in environmental conditions. The moderate underwater repertoire of the Hawaiian monk seal supports the view that males of this species serially compete for access to females that come into estrous asynchronously (Kenyon \& Rice 1959, Stirling \& Thomas 2003, Terhune 2019); it is possible that sexually mature monk seals also exhibit individual variation in seasonal patterns of breeding behavior. An 
extended reproductive period spanning half the year (as indicated for the male in this study) would increase the probability that an individual male monk seal could mate with multiple females during his breeding season.

Hawaiian monk seals appear to be candidate species for passive acoustic monitoring, which can be used to document temporal and spatial distribution patterns, estimate population abundance, and describe reproductive behavior (see e.g. Van Parijs et al. 2001, Stirling \& Thomas 2003, Van Opzeeland et al. 2010). Monk seal males are vocal for a large portion of the year, and certain sound types contain repeating and stereotyped spectral and temporal features that could be detected automatically (e.g. whoops). However, the low-frequency nature of their vocal repertoire will likely present both advantages and challenges for passive acoustics; while lowfrequency sounds propagate over long distances in water-allowing for an increased probability of detection-higher ambient noise at low frequencies may make some call types (e.g. growl, croak) difficult to detect. Ultimately, both local environmental conditions and fluctuations in background noise will affect the propagation range of these acoustic signals and determine the distances over which they are detectable.

\subsection{Estimates of communication range}

Combining information about sound reception and sound production is the best way to examine the utility of underwater signals in the marine environment. In particular, hearing thresholds and the source characteristics of vocalizations - though both types of data are not often available for a particular species can be used to estimate the range over which vocal signals may be audible to conspecifics.

Here, we can use the information available for Hawaiian monk seals to estimate underwater communication ranges with the following equation: $\mathrm{DT}=\mathrm{SL}-$ $15 \log (r)-a r$, where DT (detection threshold) is Kekoa's measured hearing threshold at the nearest audiogram frequency ${ }^{\mathbf{4}}$; SL (source level, approximated by received level here) is the SPL of each vocal type within the 1/3-octave band containing peak frequency; $15 \log (r)$ is an estimate of spreading loss ${ }^{\mathbf{5}} ; r$ is the detection distance from the source; and $a$ is the attenuation coefficient of sea water $(a=$ $0.036 f^{1.5} \mathrm{~dB} \mathrm{~km}^{-1}$, where $f$ is the peak vocal frequency in $\mathrm{kHz}_{\text {; }}$ as in Richardson et al. 1995). Based on this simplified analysis using input parameters from the present study, we find that Hawaiian monk seal vocalizations can likely be detected by conspecifics at ranges of tens to thousands of meters. Specifically, vocalizations should be detected by another monk seal from 1600, 745, 280, 75, 70, and $40 \mathrm{~m}$ away for croak, whoop, growl, groan, moan, and rumble call types, respectively. While these values will vary considerably with different acoustic conditions, the relative ranges of the call types should remain similar, with croaks and whoops extending furthest.

These communication range estimates are generated from $50 \%$ auditory performance thresholds, but it is probable that higher received amplitudes are necessary to facilitate successful communication between individuals (see e.g. Dooling \& Blumenrath 2013). On average (across frequencies), monk seal Kekoa achieved $100 \%$ detection at signal amplitudes $4 \mathrm{~dB}$ above his $50 \%$ detection thresholds. If we add $4 \mathrm{~dB}$ to our detection threshold parameter, these estimates of communication range decrease by half $(54 \%)$. It is probable that reliable discrimination and recognition and effective communication require even higher received amplitudes, thus reducing these ranges further. On the other hand, the values used for source level in this example were approximated by received levels measured at distances within $8 \mathrm{~m}$ of a calling seal. The true source levels of monk seals calling at $1 \mathrm{~m}$ are likely to be somewhat higher than these values, which would increase viable communication range for wild seals relative to these estimates. Furthermore, this analysis considered only the loudest component (peak frequency) for each call type; in reality, the entire call may provide increased opportunities for detection across multiple frequencies.

A final factor influencing these ranges is the amount of noise present in the environment. In this

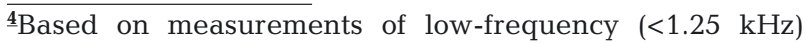
ambient noise within the Hawaiian monk seal's known range (e.g. Lammers \& Munger 2016), detection of conspecific calls under typical conditions is likely constrained by absolute hearing threshold rather than environmental noise. Kekoa's hearing thresholds at 100 and $200 \mathrm{~Hz}$ are greater than a critical ratio above the average spectral density level of the noise reported by Lammers \& Munger (2016), with critical ratios estimated based on data available for the monachid northern elephant seal and related species (see Erbe et al. 2016 for review)

${ }^{5}$ The use of $15 \log (r)$ for spreading loss is a simplification. Spherical spreading $(20 \log [r])$ will likely occur near the source, with cylindrical spreading $(10 \log [r])$ at greater distances. The actual spreading loss will depend on the local environment between the vocalizing individual and the listener(s)
} 
example, detection ranges were not limited by background noise, but an increase in natural or anthropogenic noise below $1 \mathrm{kHz}$ could limit communication ranges as well as the distances over which passive acoustic monitoring would be effective.

\section{CONCLUSIONS}

Hawaiian monk seals display elevated underwater thresholds and a narrower frequency range of hearing compared to related species. However, auditory capability below $10 \mathrm{kHz}$ (with best hearing near $1 \mathrm{kHz}$ ) is much better than previously believed, which enables them to detect conspecific vocalizations and also indicates that low-frequency anthropogenic noise is a concern for this endangered species. Despite these new audiometric data, hearing in this species - and in the Monachinae subfamily of seals - remains unresolved due to the lack of correspondence between this audiogram and either published data for Hawaiian monk seals or known audiograms for other seals. Thus, additional data for monachid seals are needed to resolve potential differences in hearing among phocid species and to consider the evolutionary bases of auditory traits.

Hawaiian monk seal males produce at least 6 underwater call types, with vocal behavior most common during a 6 mo period coincident with elevated blood testosterone levels and prior to the yearly molt. The observed annual patterns in sound production confirm a protracted reproductive season for this tropical species. The finding that underwater communication occurs in this species should guide future behavioral studies and inform conservation and management actions, including those based on passive acoustic monitoring.

This study improves understanding of acoustic biology and behavior in Hawaiian monk seals, providing updated information about underwater sound reception and the first formal documentation of sound production in water. These data can be used to mitigate the effects of disturbance on these endangered seals.

Acknowledgements. Funding for this study was provided by US Navy's Living Marine Resources Program, and we are grateful to A. Kumar and M. Shoemaker for their guidance and support. The participation of K.P. was funded by the Gates Millennium Scholars Program with additional support from the Dr. Earl H. Myers and Ethel M. Myers Oceanographic and Marine Biology Trust and the Friends of Seymour Marine Discovery Center. T.L.K. was supported in part by the Office of Naval Research. We acknowledge the significant contributions of $\mathrm{T}$. Williams and $\mathrm{B}$. Richter at the
Marine Mammal Physiology Project at the University of California Santa Cruz, without whom this animal research would not have been possible. We thank the dedicated husbandry and research teams at Long Marine Laboratory, especially T. Abraham and V. Zobell for assistance with spectrographic analysis, R. Nichols for technical support, and J. Linossier for guidance regarding statistical and acoustic analyses. We thank J. Finneran at the Navy Marine Mammal Program for providing access to the custom LabVIEW software used to measure auditory thresholds; D. Casper at the University of California for veterinary care, logistical support, and advice; L. Castle at Waikiki Aquarium for facilitating our important validation effort with a second individual; and 3 anonymous reviewers for helpful feedback that improved the manuscript. Finally, we thank Amy Sloan at the National Marine Fisheries Service and Jeff Pawloski at SeaLife Park for their long-term encouragement of our efforts to better understand auditory biology in Hawaiian monk seals. Portions of this research were presented at the 176th Meeting of the Acoustical Society of America and the 2019 World Marine Mammal Conference. The sound production portion of this study was adapted from K.P.'s MSc thesis (UC Santa Cruz, 2018). This paper represents HIMB and SOEST contribution numbers 1830 and 11156, respectively.

\section{LITERATURE CITED}

Advanced Research Projects Agency, National Oceanic and Atmospheric Administration (1995) Final environmental impact statement for the Kauai acoustic thermometry of ocean climate project and its associated marine mammal research program. Marine Acoustics, Arlington, VA

Atkinson S, Gilmartin WG (1992) Seasonal testosterone pattern in Hawaiian monk seals (Monachus schauinslandi). J Reprod Fertil 96:35-39

Berta A, Churchill M (2012) Pinniped taxonomy: review of currently recognized species and subspecies, and evidence used for their description. Mamm Rev 42: 207-234

Berta A, Churchill M, Boessenecker RW (2018) The origin and evolutionary biology of pinnipeds: seals, sea lions, and walruses. Annu Rev Earth Planet Sci 46: 203-228

* Calvert W, Stirling I (1985) Winter distribution of ringed seals (Phoca hispida) in the Barrow Strait area, Northwest Territories, determined by underwater vocalizations. Can J Fish Aquat Sci 42:1238-1243

Carretta JV, Forney KA, Oleson EM, Weller DW and others (2017) US Pacific marine mammal stock assessments: 2016. NOAA Tech Memo NMFS-SWFSC-577

Casey C, Charrier I, Mathevon N, Reichmuth C (2015) Rival assessment among northern elephant seals: evidence of associative learning during male-male contests. R Soc Open Sci 2:150228

* Charrier I, Marchesseau S, Dendrinos P, Tounta E, Karamanlidis AA (2017) Individual signatures in the vocal repertoire of the endangered Mediterranean monk seal: new perspectives for population monitoring. Endang Species Res 32:459-470

Cornsweet TN (1962) The staircase-method in psychophysics. Am J Psychol 75:485-491

Dooling RJ, Blumenrath SH (2013) Avian sound perception in noise. In: Brumm H (ed) Animal communication in noise. Springer, Heidelberg, p 229-250 
Erbe C, Reichmuth C, Cunningham K, Lucke K, Dooling R (2016) Communication masking in marine mammals: a review and research strategy. Mar Pollut Bull 103:15-38

Finneran JJ (2003) An integrated computer-controlled system for marine mammal auditory testing. SPAWAR Systems Center, San Diego, CA

Finneran JJ (2016) Auditory weighting functions and TTS/ PTS exposure functions for marine mammals exposed to underwater noise. Technical Report No. 3026. Space and Naval Warfare Systems Center Pacific, San Diego, CA

Finney DJ (1971) Probit analysis, 3rd edn. Cambridge University Press, Cambridge

Gilmartin WG, Forcada J (2009) Monk seals: Monachus monachus, $M$. tropicalis, and M. schauinslandi. In: Perrin WF, Würsig B, Thewissen JGM (eds) Encyclopedia of marine mammals, $2^{\text {nd }}$ edn. Academic Press, San Diego, CA, p 741-744

Green K, Burton HR (1988) Annual and diurnal variations in the underwater vocalizations of Weddell seals. Polar Biol 8:161-164

Job DA, Boness DJ, Francis JM (1995) Individual variation in nursing vocalizations of Hawaiian monk seal pups, Monachus schauinslandi (Phocidae, Pinnipedia), and lack of maternal recognition. Can J Zool 73:975-983

Johanos TC, Becker BL, Ragen TJ (1994) Annual reproductive cycle of the female Hawaiian monk seal (Monachus schauinslandi). Mar Mamm Sci 10:13-30

Johnson BW, Johnson PA (1984) Observations of the Hawaiian monk seal on Laysan Island from 1977 through 1980. NOAA Tech Memo NMFS-SWFC-049

Kastak D, Schusterman RJ (1999) In-air and underwater hearing sensitivity of a northern elephant seal (Mirounga angustirostris). Can J Zool 77:1751-1758

Kastelein RA, Wensveen PJ, Hoek L, Verboom WC, Terhune JM (2009) Underwater detection of tonal signals between 0.125 and $100 \mathrm{kHz}$ by harbor seals (Phoca vitulina). J Acoust Soc Am 125:1222-1229

Kenyon KW, Rice DW (1959) Life history of the Hawaiian monk seal. Pac Sci 13:215-252

Ketten DR, Wartzok D (1999) Marine mammal sensory systems. In: Reynolds JE III, Rommel SA (eds) Biology of marine mammals. Smithsonian Institution Press, Washington, DC, p 117-175

Lammers MO, Munger LM (2016) From shrimp to whales: biological applications of passive acoustic monitoring on a remote Pacific coral reef. In: Au WWL, Lammers MO (eds) Listening in the ocean: new discoveries and insights on marine life from autonomous passive acoustic recorders. Springer, New York, NY, p 61-81

Lincoln GA, Short RV (1980) Seasonal breeding: nature's contraceptive. In: Greep RO (ed) Recent progress in hormone research: Proceedings of the 1979 Laurentian Hormone Conference. Academic Press, New York, NY, p 1-52

Miller EH, Job DA (1992) Airborne acoustic communication in the Hawaiian monk seal, Monachus schauinslandi. In: Thomas JA, Kastelein RA, Supin AY (eds) Marine mammal sensory systems. Plenum Press, New York, NY, p 485-531

National Marine Fisheries Service (2018) 2018 revisions to: Technical guidance for assessing the effects of anthropogenic sound on marine mammal hearing (version 2.0): Underwater acoustic thresholds of permanent and temporary threshold shifts. NOAA Tech Memo NMFS-OPR-59

Parnell K (2018) Underwater vocal repertoire of the endangered Hawaiian monk seal, Neomonachus schauinslandi. MSc thesis, University of California, Santa Cruz, CA
R Development Core Team (2019) R: a language and environment for statistical computing. R Foundation for Statistical Computing, Vienna

Reichmuth C, Schusterman RJ (2009) Annual temporal patterning in the vocalizations of captive seals: two longterm case studies. J Acoust Soc Am 125:2676-2677

* Reichmuth C, Holt MM, Mulsow J, Sills JM, Southall BL (2013) Comparative assessment of amphibious hearing in pinnipeds. J Comp Physiol A Neuroethol Sens Neural Behav Physiol 199:491-507

Repenning CA, Ray CE (1977) The origin of the Hawaiian monk seal. Proc Biol Soc Wash 89:667-688

Richardson JW, Greene JCR, Malme CI, Thomson DH (1995) Marine mammals and noise. Academic Press, San Diego, CA

Riedman M (1990) The pinnipeds. University of California Press, Berkeley, CA

Rogers TL, Cato DH, Bryden MM (1996) Behavioral significance of underwater vocalizations of captive leopard seals, Hydurga leptonyx. Mar Mamm Sci 12:414-427

Sandegren FE (1976) Agonistic behavior in the male northern elephant seal. Behaviour 57:136-157

Sanvito S, Galimberti F, Miller EH (2007) Vocal signalling of male southern elephant seals is honest but imprecise. Anim Behav 73:287-299

Sanvito S, Galimberti F, Miller EH (2008) Development of aggressive vocalizations in male southern elephant seals (Mirounga leonina): Maturation or learning? Behaviour 145:137-170

Shipley C, Hines M, Buchwald JS (1986) Vocalizations of northern elephant seal bulls: development of adult call characteristics during puberty. J Mammal 67:526-536

Sills JM, Southall BL, Reichmuth C (2014) Amphibious hearing in spotted seals (Phoca largha): underwater audiograms, aerial audiograms and critical ratio measurements. J Exp Biol 217:726-734

* Sills JM, Southall BL, Reichmuth C (2015) Amphibious hearing in ringed seals (Pusa hispida): underwater audiograms, aerial audiograms and critical ratio measurements. J Exp Biol 218:2250-2259

Sills JM, Reichmuth C, Southall BL, Whiting A, Goodwin J (2020) Auditory biology of bearded seals (Erignathus barbatus). Polar Biol 43:1681-1691

Southall BL, Finneran JJ, Reichmuth C, Nachtigall PE and others (2019) Marine mammal noise exposure criteria: updated scientific recommendations for residual hearing effects. Aquat Mamm 45:125-232

Stirling I (1973) Vocalization in the ringed seal (Phoca hispida). J Fish Res Board Can 30:1592-1594

* Stirling I, Thomas JA (2003) Relationships between underwater vocalizations and mating systems in phocid seals. Aquat Mamm 29:227-246

* Terhune JM (2019) The underwater vocal complexity of seals (Phocidae) is not related to their phylogeny. Can J Zool 97:232-240

*Thomas JA, DeMaster DP (1982) An acoustic technique for determining diurnal activities in leopard (Hydrurga leptonyx) and crabeater (Lobodon carcinophagus) seal. Can J Zool 60:2028-2031

Thomas JA, Moore P, Withrow R, Stoermer M (1990) Underwater audiogram of a Hawaiian monk seal (Monachus schauinslandi). J Acoust Soc Am 87:417-420

*Van Opzeeland I, Van Parijs S, Bornemann H, Frickenhaus $\mathrm{S}$ and others (2010) Acoustic ecology of Antarctic pinnipeds. Mar Ecol Prog Ser 414:267-291 
Van Parijs SM (2003) Aquatic mating in pinnipeds: a review. Aquat Mamm 29:214-226

Van Parijs SM, Hastie GD, Thompson PM (1999) Geographical variation in temporal and spatial vocalization patterns of male harbour seals in the mating season. Anim Behav 58:1231-1239

Editorial responsibility: Mike Noad, Gatton, Queensland, Australia
Van Parijs SM, Kovacs KM, Lydersen C (2001) Spatial and temporal distribution of vocalising male bearded seals: implications for male mating strategies. Behaviour 138:905-922

Wyss AR (1988) On 'retrogression' in the evolution of the Phocinae and phylogenetic affinities of the monk seals. Am Mus Novit 2924:1-38

Submitted: July 10, 2020; Accepted: November 6, 2020 Proofs received from author(s): January 20, 2021 